\title{
Corn Silage Partially Replacing Short Alfalfa Hay to Optimize Forage Use in Total Mixed Rations for Lactating Cows
}

\author{
R. Kowsar, ${ }^{*}$ G. R. Ghorbani,, ${ }^{*}$ M. Alikhani, ${ }^{*}$ M. Khorvash, ${ }^{*}$ and A. Nikkhah $† \ddagger^{1}$ \\ *Department of Animal Sciences, Isfahan University of Technology, Isfahan 84156, Iran \\ †Department of Animal Sciences, University of Illinois, Urbana 61801 \\ ‡Department of Animal Sciences, Zanjan University, Zanjan, Iran
}

\section{ABSTRACT}

We theorized that adding corn silage to a total mixed ration with alfalfa hay as the sole dietary forage would improve nutrient intake and chewing activity and thereby improve rumen fermentation and milk production. The objective of this research was to determine the effects of partial replacement of short alfalfa [physically effective (pe) neutral detergent fiber (NDF) $>1.18 \mathrm{~mm}$ $\left(\right.$ peNDF $\left.\left._{>1.18}\right)=33.2 \%\right]$ with corn silage $\left(\mathrm{CS}, \mathrm{peNDF}_{>1.18}\right.$ $=51.9 \%)$ in yellow grease-supplemented total mixed rations on feed intake, chewing behavior, rumen fermentation, and lactation performance by dairy cows. Four multiparous (138 $\pm 3 \mathrm{~d}$ in milk) and 4 primiparous (115 $\pm 10 \mathrm{~d}$ in milk) Holstein cows were used in a $4 \times 4$ Latin square design experiment with four 21-d periods. Each period had $14 \mathrm{~d}$ of adaptation and $7 \mathrm{~d}$ of sampling, and parity was the square. Treatments were diets [dry matter (DM) basis] with 1) $40 \%$ alfalfa hay (ALF), 2) $24 \%$ alfalfa hay + $16 \%$ CS (CS40), 3) $20 \%$ alfalfa hay $+20 \%$ CS (CS50), and 4) $16 \%$ alfalfa hay + $24 \%$ CS (CS60). Diets had a forage-to-concentrate ratio of 40:60 on a DM basis. Cows had greater intake of DM and thus greater intakes of net energy for lactation, NDF, and peNDF when CS partially replaced alfalfa hay. Replacing alfalfa hay with CS increased daily eating and chewing times in all cows, and increased rumen $\mathrm{pH}$ at $4 \mathrm{~h}$ postfeeding in multiparous cows. Apparent total-tract digestibility coefficients for crude protein (CP) and NDF were not different among cows fed ALF, CS40, and CS50, but were lower for CS60 than for ALF. Energy-corrected milk yield was greater for CS40 and CS60 than for ALF. Milk protein yield was increased when CS replaced 40, 50, and $60 \%$ of alfalfa hay. Milk lactose was greater only for CS60, but milk lactose yield was greater for CS50 and CS60 than for ALF. Milk percentage and yield of fat did not differ among treatments. Therefore, CS partially replacing

Received April 25, 2008.

Accepted August 14, 2008.

${ }^{1}$ Corresponding author: anikkhah@uiuc.edu short alfalfa hay increased DM intake, consequently increased net energy for lactation and physically effective fiber intakes, and thus, improved milk and milk protein and lactose yields.

Key words: alfalfa hay, corn silage, Holstein, yellow grease

\section{INTRODUCTION}

Rumen health and thus, physically effective fiber requirements depend highly on forage particle size and palatability because such properties determine effective fiber intake. Fiber is effective when it can be well digested in the rumen. To be well digested, fiber needs to stimulate rumination, chewing, and salivation (Beauchemin et al., 2008). Supplemental fats can minimize negative energy balance, reduce prostaglandin synthesis, and help to maintain pregnancy by increasing linoleic acid supply (NRC, 2001). However, supplementing corn silage (CS)-based diets with unsaturated fats may depress fiber digestion, DMI, and milk fat (Jenkins and Jenny, 1989; Ruppert et al., 2003). Replacing 25 to $50 \%$ of CS with alfalfa hay has alleviated depressed milk fat and fiber digestibility caused by feeding tallow and oilseeds (Smith et al., 1993). Increased milk fat is due to increased fiber effectiveness, chewing, and salivation, which can increase rumen $\mathrm{pH}$ and fiber digestion (Beauchemin and Buchanan-Smith, 1989; Allen, 1997; Mertens, 1997). Alfalfa hay and barley grain are major fiber and starch sources in almost all commercial dairies in Iran (Nikkhah et al., 2004; Maesoomi et al., 2006). With long alfalfa hay cuts, bunk management becomes more difficult because of sorting against larger particles and feed wastage. Many dairy farmers offer longer alfalfa hay cuts as separate meals in addition to regular offers of TMR. When doing so, alfalfa cuts used in the TMR may be shorter to improve the uniformity of ration particle size and reduce the sorting of highly fermentable portions to ensure adequate effective fiber intake and reduce postfeeding decline in rumen $\mathrm{pH}$. Thus, it is imperative not only to provide adequate effective fiber in the ration but also to ensure adequate 
effective fiber intake by the cow. The latter requires shortening dry hay cuts to reduce sorting of leaves and less-fibrous fractions from highly lignocellulosic parts (Leonardi and Armentano, 2003). However, without separate alfalfa meals, the shorter alfalfa cuts in TMR may alter fiber effectiveness and rumen conditions (Onetti et al., 2004). Hence, it is important to determine optimum uses of ensiled and dry forages when alfalfa cuts are short.

Corn silage is a palatable forage that supplies, in addition to effective fiber and starch, moisture to the diet, which can reduce sorting behavior (Leonardi et al., 2005) and affect dietary DM content and feed intake (Ruppert et al., 2003; Kleinschmit et al., 2007) and diurnal patterns in rumen metabolism (Firkins et al., 2001). Alfalfa and CS are both fiber sources, but they affect rumen fermentation differently not only because of their different moisture and protein contents but also because of diverse bioenergetics. Ensilage solubilizes proteins and depresses the efficiency of ammonia, AA, and peptide assimilation into microbial mass (Beever, 1993), potentially increasing $\mathrm{N}$ loss. As a result, the amount of releasable ATP, the synchrony of ATP and $\mathrm{N}$ availability, and thereby, microbial mass yield and efficiency and milk yield will be altered by varying the TMR percentages of ensiled and dry forages. Such changes in microbial energy use are introduced with differences in particle size, altering rumen mat stratification (Welch, 1982). Moreover, these scenarios need definitive consideration of feeding yellow grease (YG) and barley grain, both of which can depress fiber digestion by reducing rumen $\mathrm{pH}$ (e.g., <5.8) and releasing toxic unsaturated fatty acids (e.g., $>1 \%$ of dietary DM; Herrera-Saldana et al., 1990; Russell and Wilson, 1996; Staples et al., 2003).

We hypothesize that partially replacing short alfalfa hay with CS increases TMR palatability and physically effective NDF (peNDF) intake, and improves rumen fermentation by retaining alfalfa hay cuts by CS particles and increasing chewing activity and rumen buffering capacity. Our objective was to determine effects of replacing 40, 50, and 60 of short alfalfa hay with CS in a TMR with YG and barley grain on diet peNDF, nutrient intake, rumen fermentation, nutrient digestibility, chewing behavior, and productivity of lactating Holstein cows.

\section{MATERIALS AND METHODS}

\section{Treatments, Experimental Design, and Cow Management}

Four multiparous $(\mathrm{BW}=656 \pm 29$ and $\mathrm{DIM}=138$ \pm 3 ; mean $\pm \mathrm{SE}$ ) and 4 primiparous $(\mathrm{BW}=525 \pm$
16 and DIM $=115 \pm 10$ ) Holstein cows were used in a $4 \times 4$ Latin square design with 21 -d periods. The Latin square was balanced for carryover effects (Cochran and Cox, 1992) and parity was the square. Each period consisted of $14 \mathrm{~d}$ of adaptation followed by $7 \mathrm{~d}$ of data collection. Cows were housed in individual boxes $(4 \times 4 \mathrm{~m})$ designed in a roofed area with open sides and were allowed $1 \mathrm{~h}$ of daily exercise. Treatment were diets with 1) $40 \%$ alfalfa hay as the sole dietary forage (ALF), control diet; 2) $24 \%$ alfalfa hay plus 16\% CS (CS40); 3) $20 \%$ alfalfa hay and 20\% CS (CS50); and 4) $16 \%$ alfalfa hay plus $24 \%$ CS (CS60) on a DM basis (Table 1). The corn crop used for ensilage was a hybrid of K74.1 × K18 called Karaj 700 and a production of about 12 to 15 t of corn crop DM/ha (Grain Breeding and Genetics Inst., Kraj, Iran). Corn was chopped by a pool type chopper (Model 965, Claas, Omaha, $\mathrm{NE}$ ) set to produce particles with an average length of 25 to $30 \mathrm{~mm}$. The chopped corn plant was ensiled in bunker silos of $30 \mathrm{~m}$ (length) $\times 4 \mathrm{~m}$ (lower width) and $5 \mathrm{~m}$ (upper width) $\times 2.5 \mathrm{~m}$ (height). Alfalfa hay was crushed by a machine conventionally used for separation of cereal grains from straw (Golchin Trasher Hay Co., Isfahan, Iran). Dietary forage to concentrate ratio was 40:60 and diets had 2\% YG. Cows were offered the TMR twice daily at 0730 and $1630 \mathrm{~h}$, permitting 5 to $10 \%$ orts with unlimited access to fresh water. Diets were formulated to be isonitrogenous using the NRC model (NRC, 2001). This experiment was conducted at the Dairy Facilities of the Lavark Research Station (Isfahan University of Technology, Isfahan, Iran) from March through June of 2006. Animals were cared for according to the guidelines of the Iranian Council of Animal Care (1995).

\section{Sampling and Laboratory Analyses}

Feed and Fecal Analysis. The amount of TMR offered and orts were measured daily from d 15 to 20 of each period to calculate DMI for individual cows. Feed and ort samples were oven-dried at $60^{\circ} \mathrm{C}$ for 48 $\mathrm{h}$, ground to pass through 1-mm screen using a Wiley mill (Arthur H. Thomas Co., Philadelphia, PA), and stored at $-20^{\circ} \mathrm{C}$ until analyzed chemically. Fecal grab samples were obtained from the rectum twice daily at 0900 and $1430 \mathrm{~h}$ during the last $5 \mathrm{~d}$ of each period and were frozen at $-20^{\circ} \mathrm{C}$ until analyzed. The frozen samples were thawed at room temperature and dried at $60^{\circ} \mathrm{C}$ for $72 \mathrm{~h}$, ground, and pooled for individual cows for each period. All samples were analyzed for CP (method 984.13; AOAC, 1990), NDF (Van Soest et al., 1991; using heat-stable $\alpha$-amylase and sodium sulfite), and ADF (method 973.18; AOAC, 1990). Organic matter was determined by ashing at $550^{\circ} \mathrm{C}$ overnight. Acid 
Table 1. Ingredient composition (\% of dietary DM) of dietary treatments

\begin{tabular}{lrrrr}
\hline & \multicolumn{4}{c}{ Treatment $^{1}$} \\
\cline { 2 - 5 } Nutrient & ALF & CS40 & CS50 & CS60 \\
\hline Alfalfa hay & 40.0 & 24.0 & 20.0 & 16.0 \\
Corn silage & 0.0 & 16.0 & 20.0 & 24.0 \\
Ground barley grain & 20.2 & 15.3 & 16.5 & 15.2 \\
Ground corn grain & 18.5 & 19.8 & 18.9 & 19.8 \\
Soybean meal & 11.2 & 14.2 & 14.1 & 15.8 \\
Canola meal & 3.3 & 3.5 & 3.3 & 2.9 \\
Cottonseed meal & 3.4 & 3.8 & 3.8 & 2.9 \\
Yellow grease & 2.0 & 2.0 & 2.0 & 2.0 \\
Sodium bicarbonate & 0.5 & 0.5 & 0.5 & 0.5 \\
Mineral and vitamins $^{2}$ & 0.9 & 0.9 & 0.9 & 0.9 \\
supplement $^{2}$ & & & & \\
\hline
\end{tabular}

${ }^{1} \mathrm{ALF}=$ all-alfalfa hay diet; $\mathrm{CS} 40=$ diet with 40:60 ratio of corn silage to alfalfa hay; $\mathrm{CS} 50=$ diet with 50:50 ratio of alfalfa hay to corn silage; CS60 = diet with 60:40 ratio of corn silage to alfalfa hay. All diets contained $40 \%$ forage on a DM basis.

${ }^{2}$ Contained vitamin A $(250,000 \mathrm{IU} / \mathrm{kg})$, vitamin D $(50,000 \mathrm{IU} / \mathrm{kg})$, and vitamin E $(1,500 \mathrm{IU} / \mathrm{kg})$, manganese $(2.25 \mathrm{~g} / \mathrm{kg})$, calcium $(120 \mathrm{~g} / \mathrm{kg})$, zinc $(7.7 \mathrm{~g} / \mathrm{kg})$, phosphorus $(20 \mathrm{~g} / \mathrm{kg})$, magnesium $(20.5 \mathrm{~g} / \mathrm{kg})$, sodium $(186 \mathrm{~g} / \mathrm{kg})$, iron $(1.25 \mathrm{~g} / \mathrm{kg})$, sulfur $(3 \mathrm{~g} / \mathrm{kg})$, copper $(1.25 \mathrm{~g} / \mathrm{kg})$, cobalt $(14 \mathrm{mg} / \mathrm{kg})$, iodine $(56 \mathrm{mg} / \mathrm{kg})$, and selenium $(10 \mathrm{mg} / \mathrm{kg})$.

detergent insoluble ash was used as an internal marker to determine apparent total-tract nutrient digestibility (Van Keulen and Young, 1977; Nikkhah et al., 2004).

Particle Size Distribution. The Penn State Particle Separator (PSPS) was used to measure particle size for the TMR and forages (Lammers et al., 1996). The daily samples were composited to obtain 2 feed samples of both TMR and forage per period for the PSPS analysis. Physically effective NDF was estimated by multiplying dietary NDF percentage by 1 ) the proportion of DM retained on the 19.0- and 8.0-mm sieves of the PSPS (peNDF $>\mathbf{8}$, Lammers et al., 1996) or 2) the proportion of DM retained on the 19.0-, 8.0-, and $1.18-\mathrm{mm}$ sieves of the PSPS $\left(\mathbf{p e N D F}_{>\mathbf{1 . 1 8}}\right.$; Mertens, 1997; Kononoff et al., 2003). After sieving, materials from each sieve were removed and dried at $55^{\circ} \mathrm{C}$ to determine DM content.

Milking and Milk Sampling. Cows were milked 3 times daily at 0430, 1200, and $2000 \mathrm{~h}$ in a milking parlor. Milk production was recorded at each milking during the final $5 \mathrm{~d}$ of each period. Before milking, cows were monitored for udder inflammation and presence of milk clots to ensure that they were not infected by mastitis. The amount of milk produced for each cow at each milking was measured using standard graduated jars (Agri \& SD Co., Frankfurt, Germany). Milk was sampled 3 times daily in prelabeled plastic vials and pooled for individual cows in equal proportions across the 3 milkings. Milk was preserved with potassium dichromate and kept at $4^{\circ} \mathrm{C}$ until analyzed for fat, pro- tein, and lactose by MilkoScan (134 BN Foss Electric, Hillerød, Denmark).

Rumen Fluid Sampling and VFA Analysis. On the last day of each experimental period, rumen fluid from the ventral sac was sampled using the rumenocentesis technique (Nordlund and Garrett, 1994). Rumen fluid samples were taken $4 \mathrm{~h}$ after morning feed delivery in 4 cows. Rumen fluid was taken at least 3 times from each cow to obtain 3 repeatable $\mathrm{pH}$ values. The $\mathrm{pH}$ of rumen fluid was measured using a mobile $\mathrm{pH}$ meter (HI 8314 membrane pH meter, Hanna Instruments, Villafranca, Italy). The rumen fluid was stabilized with sulfuric acid and frozen at $-20^{\circ} \mathrm{C}$ until VFA analysis by gas chromatography $(0.25 \times 0.32,0.3 \mu \mathrm{m}$ i.d. fused silica capillary, model no. CP-9002 Vulcanusweg 259 a.m., Chrompack, Delft, the Netherlands), as described by Bal et al. (2000).

Eating, Ruminating, and Chewing Activities. Eating and ruminating activities were monitored visually for a 24 -h period. Eating and ruminating activities were recorded by 2 alternating individuals once every 5 min under the assumption that each activity would persist for the entire 5 min (Yang et al., 2000). Total time spent chewing was calculated as the time spent eating plus the time spent ruminating. All activities were expressed per kilogram of intakes of DM, NDF, $\operatorname{peNDF}_{>8}$, and $\mathrm{peNDF}_{>1.18}$.

\section{Statistical Analysis}

Data were analyzed using the MIXED MODEL procedure (SAS Institute, 2003). The REML method was used to estimate least squares means, and the betweenwithin method was used to calculate denominator degrees of freedom. The fixed effects in the model included treatment, parity, and their interaction. The random effects were period and cow within parity. For rumen $\mathrm{pH}$ data using 4 cows as a single $4 \times 4$ Latin square design, a model with the fixed effect diet and random effects of period and cow was utilized. Normality of distribution and homogeneity of variance for residuals were tested using PROC UNIVARIATE (SAS Institute, 2003). A main practical objective of this study was to test if CS partially replacing alfalfa hay rather than feeding alfalfa hay alone leads to superior $\mathrm{DM}, \mathrm{NE}_{\mathrm{L}}$, and peNDF intakes and milk yield. Therefore, the $P$-values were specified and presented for 1) ALF vs. the average of all other diets, and 2) the linear, quadratic, and cubic effects of CS inclusion in the ration $(0,16,20$, and $24 \%$ of dietary DM) using the CONTRAST statement of SAS. Orthogonal coefficients for unequally spaced treatments were acquired using PROC IML of SAS (SAS Institute, $2003)$. The $P$-values $<0.05$ were declared as significant and those $\leq 0.10$ were set as trends. 
Table 2. Chemical composition (\% of dietary DM) of forages and diets fed to lactating cows

\begin{tabular}{|c|c|c|c|c|c|c|c|}
\hline \multirow[b]{2}{*}{ Nutrient } & \multicolumn{2}{|c|}{ Forage } & \multicolumn{4}{|c|}{ Treatment $^{1}$} & \multirow[b]{2}{*}{ SEM } \\
\hline & Alfalfa hay & Corn silage & ALF & CS40 & CS50 & CS60 & \\
\hline DM, \% & 95.2 & 24.1 & $67.1^{\mathrm{a}}$ & $61.6^{\mathrm{b}}$ & $58.5^{\mathrm{c}}$ & $53.7^{\mathrm{d}}$ & 0.01 \\
\hline $\mathrm{NE}_{\mathrm{L}}, \mathrm{Mcal} / \mathrm{kg}$ & 1.38 & 1.36 & 1.50 & 1.58 & 1.60 & 1.63 & - \\
\hline $\mathrm{CP}, \%$ & 14.2 & 8.6 & 17.2 & 16.9 & 17.4 & 16.5 & 0.43 \\
\hline NDF, $\%$ & 43.4 & 52.0 & 39.5 & 40.3 & 40.4 & 41.7 & 1.5 \\
\hline Forage NDF, $\%$ & - & - & 17.4 & 18.7 & 19.1 & 19.4 & 1.1 \\
\hline $\mathrm{ADF}, \%$ & 34.2 & 37.4 & $18.9^{\mathrm{a}}$ & $18.7^{\mathrm{a}}$ & $16.8^{\mathrm{b}}$ & $17.1^{\mathrm{b}}$ & 0.7 \\
\hline $\mathrm{NFC}^{2} \%$ & 29.4 & 27.9 & 30.5 & 30.8 & 30.0 & 29.8 & 1.0 \\
\hline Ether extract, \% & 2.5 & 2.5 & 2.7 & 2.8 & 2.7 & 2.4 & - \\
\hline Ash, \% & 10.5 & 9.0 & 10.1 & 9.2 & 9.5 & 9.6 & 0.5 \\
\hline
\end{tabular}

${ }^{\mathrm{a}-\mathrm{d}}$ Values with different superscripts within a row indicate a significant difference, $P<0.05$.

${ }^{1} \mathrm{ALF}=$ all-alfalfa hay diet; $\mathrm{CS} 40=$ diet with 40:60 ratio of corn silage to alfalfa hay; $\mathrm{CS} 50=$ diet with 50:50 ratio of alfalfa hay to corn silage; CS60 = diet with 60:40 ratio of corn silage to alfalfa hay. Nutrient composition was compared among diets using feed sample replicates from each experimental period in a completely randomized design model. All diets contained $40 \%$ forage on a DM basis.

${ }^{2} \mathrm{NFC}=100-(\mathrm{CP} \%+\mathrm{NDF} \%+$ ether extract $\%+$ ash $\%)$.

\section{RESULTS}

\section{Nutrient Composition, Particle Size Distribution, and Physical Effectiveness of Forages and TMR}

Chemical composition of the experimental diets and forages is presented in Table 2. As CS replaced 40, 50, and $60 \%$ of alfalfa hay, dietary $\mathrm{DM}$ decreased and $\mathrm{NE}_{\mathrm{L}}$ concentration increased $(P<0.05)$. The percentages of $\mathrm{CP}, \mathrm{NDF}$, and ash were not different among diets.

The proportions of the particles retained on the top sieve of the PSPS $(>19 \mathrm{~mm})$ was greater $(P<0.01)$ for CS40, CS50, and CS60 rations than for ALF (Table $3)$. The percentages of particles retained on the second sieve $(8-19 \mathrm{~mm})$ were also greater for TMR with CS than for ALF. The percentages of particles retained on the second sieve were greater in CS60 than in other rations. The percentage of the particles with an average size of 1.18 to $8 \mathrm{~mm}$ was greater in the ALF diet compared with other diets (Table 3). Replacing 60\% but not 40 and $50 \%$ of alfalfa hay with CS decreased $(P<0.05)$ the percentage of the particles retained on the bottom pan $(<1.18 \mathrm{~mm})$. The $\mathrm{peNDF}_{>1.18}$ was comparable among ALF, CS40, and CS50 diets. The peNDF $_{>1.18}$ of CS60 was greater than that of ALF and CS40 $(P<0.05)$, but was comparable with that of CS50 (Table 3). The diet peNDF $>8$ increased by adding CS to the ration. This increase was greater for CS60 than for CS40 and CS50 diets (Table 3).

\section{DM, Net Energy, and Fiber Intakes, and Eating, Ruminating, and Chewing Times}

Replacing 40, 50, and $60 \%$ of alfalfa hay with CS linearly increased $(P<0.01) \mathrm{DM}, \mathrm{NE}_{\mathrm{L}}, \mathrm{NDF}, \mathrm{peNDF}_{>8}$, and $\mathrm{peNDF}_{>1.18}$ intakes (Table 4). Adding CS to the ration tended to linearly increase $(P=0.07)$ daily eating time but not eating time per kilogram of DMI (Table 4). The average daily eating time for cows fed diets with CS was greater $(P=0.05)$ than for cows fed ALF. Eating time per kilogram of peNDF $_{>8}$ intake $(P<0.01)$ and per kilogram of peNDF $>1.18$ intake $(P$ $=0.04)$ decreased linearly as CS replaced 40, 50, and $60 \%$ of alfalfa hay. Total daily ruminating time was unaffected by treatment. Inclusion of CS in the diet tended to linearly decrease $(P=0.08)$ ruminating time per kilogram of NDF intake and linearly decreased ruminating time per kilogram of peNDF $>8$ intake $(P<$ $0.01)$ and peNDF $>1.18$ intake $(P=0.04)$. Daily chewing time increased linearly $(P=0.03)$ in response to the increasing addition of CS to the diet. However, chewing time per kilogram of NDF intake $(P=0.04)$, peNDF $>8$ intake $(P<0.01)$, and peNDF $>1.18$ intake $(P<0.01)$ decreased linearly as CS partially replaced alfalfa hay.

Multiparous cows tended to consume greater $\mathrm{NE}_{\mathrm{L}}(P$ $=0.10), \operatorname{peNDF}_{>8}(P=0.09)$, and $\operatorname{peNDF}_{>1.18}(P=$ 0.10) compared with primiparous cows. Daily eating time $(P=0.02)$ and eating time per kilogram of intakes of DMI, NDF, and peNDF $>1.18(P=0.01)$ were greater in primiparous cows than in multiparous cows. In addition, primiparous cows had greater ruminating and chewing times daily and per kilogram of DM, NDF, and peNDF intake (Table 4).

\section{Rumen Fermentation}

Except for rumen $\mathrm{pH}$, fermentation parameters across the 3 CS diets were comparable to those of the ALF diet (Table 5). Adding CS to the ALF diet linearly increased rumen $\mathrm{pH}(P=0.02)$. Primiparous cows had lower rumen $\mathrm{pH}(P=0.02)$ and greater VFA concen- 
Table 3. Particle size distribution (\% of total particles) and effective NDF content of alfalfa hay, corn silage, and TMR measured using the Penn State Particle Separator (PSPS)

\begin{tabular}{|c|c|c|c|c|c|c|}
\hline \multirow[b]{2}{*}{ Particle size } & \multicolumn{2}{|c|}{ Forage } & \multicolumn{4}{|c|}{ Treatment $^{1}$} \\
\hline & Alfalfa hay & Corn silage & ALF & CS40 & CS50 & CS60 \\
\hline$>19 \mathrm{~mm}$ & 4.1 & 32.5 & $2.4^{\mathrm{b}}$ & $6.5^{\mathrm{a}}$ & $5.0^{\mathrm{a}}$ & $8.3^{\mathrm{a}}$ \\
\hline $19.0-8.0 \mathrm{~mm}$ & 28.1 & 54.7 & $17.2^{\mathrm{c}}$ & $22.0^{\mathrm{b}}$ & $21.0^{\mathrm{b}}$ & $27.2^{\mathrm{a}}$ \\
\hline $8.0-1.18 \mathrm{~mm}$ & 44.3 & 12.7 & $68.3^{\mathrm{a}}$ & $58.4^{\mathrm{b}}$ & $61.3^{\mathrm{b}}$ & $57.4^{\mathrm{b}}$ \\
\hline$<1.18 \mathrm{~mm}$ & 23.5 & 0.1 & $12.1^{\mathrm{a}}$ & $13.0^{\mathrm{a}}$ & $12.7^{\mathrm{a}}$ & $7.1^{\mathrm{b}}$ \\
\hline $\operatorname{peNDF}_{>1,18}{ }^{2}$ & 33.2 & 51.9 & $34.7^{\mathrm{b}}$ & $35.1^{\mathrm{b}}$ & $35.3^{\text {ab }}$ & $38.8^{\mathrm{a}}$ \\
\hline $\mathrm{peNDF}_{>8}$ & 14.0 & 45.3 & $7.7^{\mathrm{c}}$ & $11.5^{\mathrm{b}}$ & $10.5^{\mathrm{b}}$ & $14.9^{\mathrm{a}}$ \\
\hline
\end{tabular}

${ }^{\text {a-c }}$ Within each treatment row, values with different superscripts differ at $P<0.05$. The PSPS data were compared among treatments as a mixed model with fixed effects of diet and period using periodical measurements.

${ }^{1} \mathrm{ALF}=$ all-alfalfa hay diet; $\mathrm{CS} 40=$ diet with 40:60 ratio of corn silage to alfalfa hay; CS50 = diet with 50:50 ratio of alfalfa hay to corn silage; CS60 = diet with 60:40 ratio of corn silage to alfalfa hay. The PSPS data for CS represent a single periodical sample. All diets contained $40 \%$ forage on a DM basis.

${ }^{2} \mathrm{NDF}$ content of TMR or forage multiplied by their physical effective factor (pef) or the proportion of particles retained on the 19-, 8-, and 1.18-mm sieves of the PSPS (Mertens, 1997; Kononoff et al., 2003).

${ }^{3} \mathrm{NDF}$ content of TMR or forage multiplied by its pef or the proportion of particles retained on the 19- and 8-mm sieves of the PSPS (Lammers et al., 1996).

trations $(P=0.04)$ than did multiparous cows. Rumen acetate showed a quadratic response to adding CS. The acetate to propionate ratio showed a cubic response to CS addition. The ratio increased at $40 \%$ replacement, decreased at $50 \%$ replacement, and increased again at $60 \%$ replacement. Acetate concentration tended to be greater in primiparous cows than in multiparous cows $(P=0.10)$. A cubic effect of CS on total rumen VFA existed such that CS replacing only $40 \%$ of alfalfa increased rumen VFA concentrations, but CS replacing $50 \%$ of alfalfa hay decreased it $(P=0.03)$.

\section{Apparent Total-Tract Nutrient Digestibility}

The apparent total-tract DM $(P=0.07)$ and $\mathrm{OM}$ $(P=0.08)$ digestibility coefficients tended to decrease and that of ADF decreased linearly $(P=0.01)$ as CS replaced alfalfa hay. Treatments did not affect $\mathrm{CP}$ and NDF digestibility (Table 6). Primiparous cows digested a greater portion of dietary NDF $(P=0.01)$ and tended to have greater $\mathrm{CP}(P=0.06)$ and greater $(P=0.07)$ $\mathrm{ADF}, \mathrm{DM}$, and $\mathrm{OM}$ total-tract digestibility compared with multiparous cows (Table 6).

\section{Milk Production}

Milk yield increased when CS was added to the ALF diet $(P=0.03$; Table 7$)$. Fat-corrected milk yield showed a cubic response to CS addition $(P=0.02)$. Energy-corrected milk yield tended to increase in a linear $(P=0.07)$ and cubic $(P=0.08)$ manner when CS partially replaced alfalfa hay. Feed efficiency was greater for $\operatorname{ALF}(P=0.02)$ than for diets with CS. Milk fat percentage did not change with the treatments, but milk fat yield tended to increase cubically $(P=0.10)$ as CS was increased in the diet (Table 7). Milk protein percentage $(P=0.02)$ and milk protein yield $(P<$ 0.01) increased linearly as CS replaced alfalfa hay. The increasing inclusion of CS in the ALF diet linearly increased milk lactose yield $(P=0.02)$ with a tendency to increase milk lactose percentage $(P=0.07)$. Primiparous cows had greater milk lactose percentage than did multiparous cows $(P=0.04$, Table 7$)$.

\section{DISCUSSION}

\section{Diet Composition and Nutrient Intake}

High-quality CS is a palatable forage in part because of its uniform particle size distribution and high moisture content, which reduce ration dustiness and increase peNDF intake. The relationship between DMI and dietary moisture is not conclusive (NRC, 2001). The markedly greater intake of diets with CS compared with ALF suggests a positive effect of CS on diet palatability. Whole, raw soybean has been shown to reduce DMI to a greater extent in a diet with finer forage than in a diet with coarser forage (Grant and Weidner, 1992). Alfalfa hay was finer than CS in our study, providing evidence that when diets contain unsaturated fats, a combination of ensiled and short dry forages simultaneously increases $\mathrm{DM}$ and $\mathrm{NE}_{\mathrm{L}}$ intakes. Diets with $\mathrm{CS}$ had greater peNDF $>1.18$ than the ALF diet. A reduction in diet peNDF may increase DMI (Schwab et al., 2002). However, DMI decreased for the ALF diet in our study, strengthening the premise that forage palatability and particle size can overshadow peNDF effects on DMI. Uniquely, the greater dietary peNDF in rations with a 
Table 4. Treatment effects on $\mathrm{NE}_{\mathrm{L}}$, DM, and fiber intakes and on eating, ruminating, and chewing activities

\begin{tabular}{|c|c|c|c|c|c|c|c|c|c|c|c|c|}
\hline \multirow[b]{2}{*}{ Item } & \multicolumn{4}{|c|}{ Treatment $^{1}$} & \multicolumn{2}{|c|}{ Parity $(\text { Par })^{1}$} & \multirow[b]{2}{*}{$\mathrm{SE}$} & \multicolumn{5}{|c|}{ Contrast $P$-value } \\
\hline & ALF & CS40 & CS50 & CS60 & M & $\mathrm{P}$ & & Par & Alf vs. CS & Linear & Quadratic & Cubic \\
\hline $\mathrm{NE}_{\mathrm{L}}$ intake, Mcal/d & 30.2 & 35.1 & 39.7 & 39.3 & 38.5 & 33.7 & 1.6 & 0.10 & $<0.01$ & $<0.01$ & 0.73 & 0.09 \\
\hline DMI, $\mathrm{kg} / \mathrm{d}$ & 20.1 & 22.2 & 24.9 & 24.1 & 21.3 & 24.3 & 1.1 & 0.11 & $<0.01$ & $<0.01$ & 0.88 & 0.08 \\
\hline NDF intake, $\mathrm{kg} / \mathrm{d}$ & 7.8 & 9.0 & 10.1 & 10.0 & 9.9 & 8.6 & 0.5 & 0.11 & $<0.01$ & $<0.01$ & 0.51 & 0.14 \\
\hline $\mathrm{peNDF}_{>8}$ intake, $\mathrm{kg} / \mathrm{d}$ & 1.4 & 2.5 & 2.6 & 3.6 & 2.8 & 2.4 & 0.2 & 0.09 & $<0.01$ & $<0.01$ & $<0.01$ & $<0.01$ \\
\hline $\mathrm{peNDF}_{>1.18}$ intake, $\mathrm{kg} / \mathrm{d}$ & 6.9 & 7.7 & 8.8 & 9.3 & 8.9 & 7.8 & 0.4 & 0.10 & $<0.01$ & $<0.01$ & 0.05 & 0.39 \\
\hline \multicolumn{13}{|l|}{ Eating time } \\
\hline $\min / \mathrm{d}$ & 327.8 & 354.1 & 354.2 & 353.3 & 314.5 & 380.1 & 17.7 & 0.02 & 0.05 & 0.07 & 0.42 & 0.96 \\
\hline $\mathrm{min} / \mathrm{kg}$ of $\mathrm{DMI}$ & 16.5 & 16.5 & 14.6 & 15.0 & 13.1 & 18.3 & 1.2 & 0.01 & 0.34 & 0.22 & 0.51 & 0.22 \\
\hline $\mathrm{min} / \mathrm{kg}$ of NDF intake & 42.9 & 41.0 & 36.3 & 36.0 & 32.3 & 45.2 & 3.3 & 0.01 & 0.18 & 0.09 & 0.37 & 0.30 \\
\hline $\min / \mathrm{kg}$ of $\mathrm{peNDF}_{>8}$ intake & 215.3 & 147.1 & 139.4 & 102.5 & 124.7 & 174.0 & 16.8 & 0.01 & $<0.01$ & $<0.01$ & 0.43 & 0.17 \\
\hline $\mathrm{min} / \mathrm{kg}$ of $\mathrm{peNDF} \mathrm{N}_{>1.18}$ intake & 47.7 & 47.1 & 41.3 & 38.7 & 36.5 & 51.0 & 4.3 & 0.01 & 0.13 & 0.04 & 0.12 & 0.46 \\
\hline \multicolumn{13}{|l|}{ Ruminating time } \\
\hline $\min / \mathrm{d}$ & 414.7 & 431.4 & 434.0 & 449.0 & 395.7 & 468.8 & 20.4 & $<0.01$ & 0.39 & 0.32 & 0.76 & 0.83 \\
\hline $\mathrm{min} / \mathrm{kg}$ of DMI & 20.9 & 19.9 & 17.7 & 19.2 & 16.5 & 22.4 & 1.3 & $<0.01$ & 0.23 & 0.21 & 0.84 & 0.23 \\
\hline $\mathrm{min} / \mathrm{kg}$ of NDF intake & 53.0 & 49.3 & 44.0 & 46.0 & 41.0 & 55.0 & 3.2 & $<0.01$ & 0.11 & 0.08 & 0.97 & 0.30 \\
\hline $\mathrm{min} / \mathrm{kg}$ of $\mathrm{peNDF}_{>8}$ intake & 281.0 & 174.9 & 169.8 & 132.6 & 159.1 & 212.3 & 18.1 & $<0.01$ & $<0.01$ & $<0.01$ & 0.97 & 0.23 \\
\hline $\mathrm{min} / \mathrm{kg}$ of $\mathrm{peNDF} \mathrm{F}_{>1.18}$ intake & 62.0 & 56.7 & 50.3 & 49.4 & 46.0 & 62.2 & 4.4 & $<0.01$ & 0.08 & 0.04 & 0.48 & 0.44 \\
\hline \multicolumn{13}{|l|}{ Chewing time } \\
\hline $\min / \mathrm{d}$ & 734.6 & 785.4 & 788.2 & 802.3 & 706.3 & 849.0 & 25.2 & $<0.01$ & 0.03 & 0.03 & 0.85 & 0.78 \\
\hline $\mathrm{min} / \mathrm{kg}$ of DMI & 37.3 & 36.4 & 32.3 & 34.2 & 29.5 & 40.6 & 2.5 & $<0.01$ & 0.19 & 0.13 & 0.81 & 0.12 \\
\hline $\mathrm{min} / \mathrm{kg}$ of NDF intake & 97.3 & 90.4 & 80.5 & 82.0 & 72.9 & 100.5 & 6.3 & $<0.01$ & 0.07 & 0.04 & 0.58 & 0.18 \\
\hline $\mathrm{min} / \mathrm{kg}$ of $\mathrm{peNDF}>8$ intake & 495.2 & 322.0 & 309.0 & 235.5 & 283.3 & 386.4 & 25.3 & $<0.01$ & $<0.01$ & $<0.01$ & 0.64 & 0.11 \\
\hline $\mathrm{min} / \mathrm{kg}$ of $\mathrm{peNDF}_{>1.18}$ intake & 107.4 & 103.7 & 92.6 & 88.2 & 82.2 & 113.2 & 6.9 & $<0.01$ & 0.04 & 0.01 & 0.16 & 0.32 \\
\hline
\end{tabular}

${ }^{1} \mathrm{ALF}=$ all-alfalfa hay diet; CS40 = diet with 40:60 ratio of corn silage to alfalfa hay; CS50 = diet with 50:50 ratio of alfalfa hay to corn silage; CS60 = diet with 60:40 ratio of corn silage to alfalfa hay. $\mathrm{M}=$ multiparous, $\mathrm{P}=$ primiparous. All diets contained $40 \%$ forage on a DM basis. 


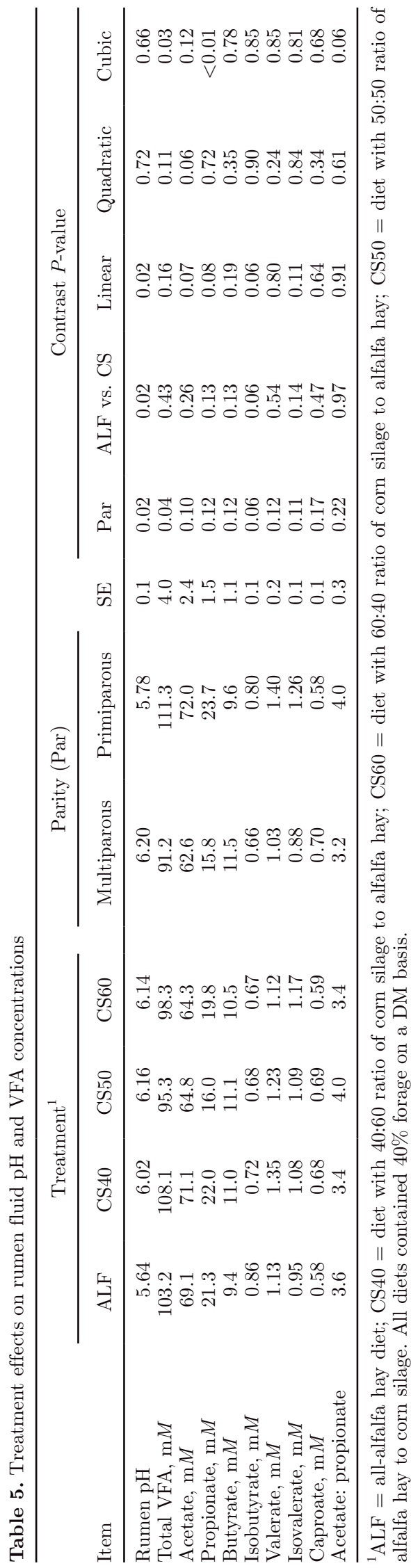

mixture of CS and alfalfa hay increased DM, peNDF, and $\mathrm{NE}_{\mathrm{L}}$ intakes. We suggest that the concomitant increases in effective fiber and energy intakes, which has been difficult to achieve in high-producing cows, was due, in part, to increased diet moisture and palatability by CS. The tendency for greater DMI of multiparous cows than of primiparous cows agrees with other reports (Beauchemin and Rode, 1997).

\section{Eating, Ruminating, and Chewing Times}

The increased intakes of $\mathrm{peNDF}_{>1.18}$ and $\mathrm{peNDF}_{>8}$ explain the increased eating time in CS-fed cows. Cows on CS diets consumed about $80 \%$ more peNDF $_{>8}$ than cows on ALF, whereas the value for $\mathrm{peNDF}_{>1.18}$ intake was $21 \%$. Thus, the peNDF $>8$ intake was more sensitive to treatments than the peNDF $>1.18$ intake. Decreased ruminating time per kilogram of peNDF $>8$ and $\mathrm{peNDF}_{>1.18}$ intakes by adding $\mathrm{CS}$ to the ration reflects the treatment differences in DMI via altered ration particle size distribution and moisture. Large particles can retain smaller particles and improve the consistency of the fiber mat (Grant, 1997). A larger rumen fiber mat provides adequate time for digestion (Welch, 1982). In our study, CS had greater proportions of particles retained on the $19-\mathrm{mm}$ (32.5 vs. $4.1 \%$ ) and $8-\mathrm{mm}$ ( 54.7 vs. $28.1 \%$ ) sieves of the PSPS than did alfalfa hay. The coarser CS may have effectively retained the finer alfalfa particles and improved rumen mat consistency, thus highlighting the significance of increased ration moisture and palatability in improving peNDF intake by feeding a uniform mixture of ensiled and dry forages.

Increased total chewing time by $\mathrm{CS}$ was due to the extended eating time. Increased $\mathrm{peNDF}_{>8}$ intake and reduced chewing time per kilogram of $\mathrm{peNDF}_{>8}$ intake indicated that treatment cows chewed fiber more efficiently than did the ALF cows. In steers with free access to wheat straw during a 3 -h period, the eating energy cost was about $6.5 \mathrm{cal}$ of $\mathrm{ME} / \mathrm{min}$ per $\mathrm{kg}$ of $\mathrm{BW}$ (Susenbeth et al., 1998). Assuming that the ruminating energy cost is about $27 \%$ of the eating energy cost (Susenbeth et al., 1998), the total chewing energy cost would be $8.3 \mathrm{cal}$ of $\mathrm{ME} / \mathrm{min}$ per $\mathrm{kg}$ of $\mathrm{BW}$. Cows on CS40, CS50, and CS60 spent, respectively, 322, 309, and 235 min chewing per $\mathrm{kg}$ of peNDF $_{>8}$ intake, but ALF cows spent $495 \mathrm{~min}$ chewing. Meanwhile, the CS40, CS50, and CS60 cows consumed, respectively, 16,31 , and $30 \%$ more $\mathrm{NE}_{\mathrm{L}}$ and 79,85 , and $157 \%$ more peNDF $_{>8}$ than the ALF cows. Thus, ALF, CS40, CS50, and CS60 cows would spend about 1.94, 1.26, 1.21, and 0.92 Mcal of $\mathrm{NE}_{\mathrm{L}}$ per $\mathrm{kg}$ of peNDF $>8$ intake, suggesting that CS60 cows required almost half the energy to effectively chew and process dietary NDF, compared 
Table 6. Treatment effects on apparent total-tract nutrient digestibility

\begin{tabular}{|c|c|c|c|c|c|c|c|c|c|c|c|c|}
\hline Item & \multicolumn{4}{|c|}{ Treatment $^{1}$} & \multicolumn{2}{|c|}{ Parity (Par) } & SE & \multicolumn{5}{|c|}{ Contrast $P$-value } \\
\hline DM, \% & 75.6 & 73.0 & 72.0 & 72.0 & 71.8 & 74.5 & 1.9 & 0.07 & 0.08 & 0.07 & 0.84 & 0.78 \\
\hline $\mathrm{CP}, \%$ & 76.0 & 73.7 & 73.3 & 72.3 & 72.1 & 75.5 & 1.8 & 0.06 & 0.18 & 0.15 & 0.92 & 0.91 \\
\hline NDF, $\%$ & 68.1 & 66.3 & 65.4 & 66.1 & 64.3 & 68.6 & 2.2 & 0.01 & 0.29 & 0.29 & 0.78 & 0.73 \\
\hline $\mathrm{ADF}, \%$ & 61.9 & 58.1 & 53.0 & 54.0 & 54.8 & 58.8 & 2.7 & 0.07 & 0.02 & 0.01 & 0.74 & 0.24 \\
\hline
\end{tabular}

${ }^{1} \mathrm{ALF}=$ all-alfalfa hay diet; CS40 = diet with 40:60 ratio of corn silage to alfalfa hay; CS60 = diet with 60:40 ratio of corn silage to alfalfa hay; CS50 $=$ diet with 50:50 ratio of alfalfa hay to corn silage. All diets contained 40\% forage on a DM basis.

with ALF cows. The CS60 cows would spend 3.93 Mcal of ME for daily chewing, whereas the ALF cows would spend 3.60 Mcal, corresponding to 8 and $9.5 \%$ of their daily ME intakes, respectively. Hence, the ME spent for chewing would be 0.33 Mcal greater for CS60 than for ALF, which is considerable and accounts for about $0.4 \mathrm{~kg}$ of ECM (NRC, 2001) or 19\% of the increase in ECM when CS replaced $60 \%$ of alfalfa hay (34.0 vs. $31.9 \mathrm{~kg} / \mathrm{d}$ ). Given the greater rumen $\mathrm{pH}$ for CS60 compared with ALF, CS60 enabled cows to spend less time chewing to maintain healthy rumen conditions while DMI increased. The decreased time required to chew dietary fiber indicates that CS60 enhanced the physical effectiveness per unit of NDF intake, allowing cows to improve rumen conditions and produce greater milk protein, fat, and lactose. Active fats may depress fiber digestion and increase peNDF requirements (Palmquist and Jenkins, 1980; Onetti et al., 2004). Our data suggest that a uniform mixture of short alfalfa hay and CS favors NDF effectiveness and intake, chewing activity, and milk production in barley grain-based diets supplemented with YG.

\section{Rumen $\mathrm{pH}$ and VFA}

Increased rumen $\mathrm{pH}$ by treatments suggests that $\mathrm{CS}$ stabilized the rumen environment. The rumen $\mathrm{pH}$ increased while cows fed CS had greater DMI, suggesting that fermentation was improved by greater peNDF intake. These data were consistent with increased chewing time. Total rumen VFA concentrations were, however, greater only when CS40 was fed, which may be related to the greater DMI and likely a greater rumen outflow rate for CS50 and CS60. The lower rumen $\mathrm{pH}$ and greater VFA in primiparous compared with multiparous cows can be explained by the greater DMI of multiparous cows, which may have increased rumen outflow rate. This reasoning is supported by the increased daily chewing time in primiparous cows. Increased chewing time means increased microbial access to feed particles and increased rumen VFA production and lower $\mathrm{pH}$.

\section{Apparent Total-Tract Nutrient Digestibility}

Nutrient digestibility may decrease when unsaturated fats are fed with CS (Smith et al., 1993). The tendency for decreased DM digestibility by CS can partly be explained by the greater DMI for CS50 and CS60, likely a greater rumen outflow rate, and decreased chewing time per kilogram of fiber intake (Nelson and Satter, 1990). The chewing time per kilogram of $\mathrm{peNDF}_{>8}$ intake was lower for cows fed CS, which may have contributed to reduced ADF digestibility. It should be noted that lower nutrient digestibility coefficients do not necessarily mean lower nutrient availability because CS-fed cows consumed much greater amounts of DM and $\mathrm{NE}_{\mathrm{L}}$ than did ALF cows.

\section{Milk Production}

Milk fat yield tended to increase with CS because of changes in milk volume. The greater ECM yield for CS compared with ALF may be because of increased $\mathrm{NE}_{\mathrm{L}}$ intake. For feed efficiency, the CS40 diet had the optimum alfalfa hay to CS ratio because of its numerically greater DMI and greater FCM yield than the ALF group. The linear increase in milk protein by adding CS was consistent with increased $\mathrm{NE}_{\mathrm{L}}$ intake, because milk protein is positively related to energy and rumen fermentable OM intake (DePeters and Cant, 1992). Increased peNDF intake and chewing time, and thereby, elevated rumen $\mathrm{pH}$ by feeding a mixture of CS and short alfalfa hay may have favored microbial metabolism. The increased lactose yield agrees with the increased $\mathrm{NE}_{\mathrm{L}}$ intake.

Smith et al. (1993) found that depressed milk fat percentage by feeding CS with $2.5 \%$ tallow was overcome by alfalfa hay replacing 25 or $50 \%$ of CS. Dietary NDF increased considerably when alfalfa hay replaced CS (Smith et al., 1993). In our study, dietary NDF was comparable among treatments enabling us to specify treatment effects on milk fat independent from fiber effects. Griinari et al. (1998) suggested that unsaturated fats coupled with low rumen $\mathrm{pH}$ contribute to forming 
trans-10 octadecenoic acid, which was associated with milk fat depression. Partial replacement of alfalfa hay with CS increased peNDF intake and chewing time, which, together with similar milk fat percentages, suggests that trans fatty acid production pathways were unaltered by treatments. Enriched milk protein lends support to favored rumen conditions by feeding a combination of CS and short alfalfa. Thus, we intuit that forage palatability is influential and needs to be considered in determining fiber effectiveness and predicting rumen function and milk yield. An optimum mixture of ensiled and dry forages that increases ration uniformity, reduces sorting, and increases both peNDF and $\mathrm{NE}_{\mathrm{L}}$ intakes will improve rumen health and milk secretion when highly fermentable starch and unsaturated fats are fed.

\section{CONCLUSIONS}

In diets containing barley grain and yellow grease, replacing 40,50 , and $60 \%$ of short alfalfa hay with CS increased dietary moisture and $\mathrm{DM}, \mathrm{NE}_{\mathrm{L}}$, and peNDF intakes. The simultaneous increase in effective fiber and net energy intake was associated with increased chewing time. Rumen $\mathrm{pH}$ also increased when CS partially replaced alfalfa hay. Crude protein and NDF total-tract digestibility coefficients did not change by treatments. Adding CS to the ration improved ECM yield and milk lactose and protein percentages and yields. Results support the premise that a uniform combination of ensiled and short dry forages in TMR increases energy and peNDF intakes simultaneously, and thereby, increases milk synthesis without compromising rumen function and the need for additional dietary concentrate. Findings will have metabolic implications during early and peak lactation when DMI is insufficient.

\section{ACKNOWLEDGMENTS}

The authors gratefully acknowledge Isfahan University of Technology (IUT, Isfahan, Iran) for financial support and teaching and research services, and the staff at Lavark Research Station (IUT) for animal care. Thanks to Jim Drackley and Mike Murphy of the Department of Animal Sciences at the University of Illinois (Urbana) for their views on the manuscript and discussions of the statistics.

\section{REFERENCES}

Allen, M. S. 1997. Relationship between fermentation acid production in the rumen and the requirement for physically effective fiber. J. Dairy Sci. 80:1447-1462.

AOAC. 1990. Official Methods of Analysis. 15th ed. Assoc. Offic. Anal. Chem., Arlington, VA. 
Bal, M. A., R. D. Shaver, A. G. Jirovec, K. J. Shinners, and J. G Coors. 2000. Crop processing and chop length of corn silage: Effects on intake, digestion, and milk production by dairy cows. J. Dairy Sci. 83:1264-1273.

Beauchemin, K. A., and J. G. Buchanan-Smith. 1989. Effects of dietary neutral detergent fiber concentration and supplementary long hay on chewing activities and milk production of dairy cows. J. Dairy Sci. $72: 2288-2300$.

Beauchemin, K. A., L. Eriksen, P. Nørgaard, and L. M. Rode. 2008. Salivary secretion during meals in lactating dairy cattle. J. Dairy Sci. 91:2077-2081.

Beauchemin, K. A., and L. M. Rode. 1997. Minimum versus optimum concentrations of fiber in dairy cow diets based on barley silage and concentrates of barley or corn. J. Dairy Sci. 80:1629-1639.

Beever, D. E. 1993. Rumen function. Pages 187-215 in Quantitative Aspects of Ruminant Digestion and Metabolism. 1st ed. J. M. Forbes and J. France, ed. CABI Publishing, Wallingford, UK.

Cochran, W. G., and G. M. Cox. 1992. Experimental Designs. 2nd ed. Wiley-Interscience Publications, New York, NY.

DePeters, E. J., and J. P. Cant. 1992. Nutritional factors influencing the nitrogen composition of bovine milk: A review. J. Dairy Sci. $75: 2043-2070$

Firkins, J. L., M. L. Eastridge, N. R. St-Pierre, and S. M. Noftsger. 2001. Effects of grain variability and processing on starch utilization by lactating dairy cattle. J. Dairy Sci. 79(E Suppl.):E218-E238.

Grant, R. J. 1997. Interactions among forages and nonforage fiber sources. J. Dairy Sci. 80:1438-1446.

Grant, R. J., and S. J. Weidner. 1992. Effect of fat from whole soybeans on performance of dairy cows fed rations differing in fiber level and particle size. J. Dairy Sci. 75:2742-2751.

Griinari, J. M., D. A. Dwyer, M. A. McGuire, D. E. Bauman, D. L. Palmquist, and K. V. V. Nurmela. 1998. Trans-octadecenoic acids and milk fat depression in lactating dairy cows. J. Dairy Sci. 81:1251-1261

Herrera-Saldana, R. E., J. T. Huber, and M. H. Poore. 1990. Dry matter, crude protein, and starch degradability of five cereal grains. J. Dairy Sci. 73:2386-2393.

Iranian Council of Animal Care. 1995. Guide to the Care and Use of Experimental Animals. Vol. 1. Isfahan University of Technology, Isfahan, Iran.

Jenkins, T. C., J. A. Bertrand, and W. C. Bridges Jr. 1998. Interactions of tallow and hay particle size on yield and composition of milk from lactating Holstein cows. J. Dairy Sci. 81:1396-1402.

Jenkins, T. C., and B. F. Jenny. 1989. Effect of hydrogenated fat on feed intake, nutrient digestion, and lactation performance of dairy cows. J. Dairy Sci. 72:2316-2324.

Kleinschmit, D. H., D. J. Schingoethe, A. R. Hippen, and K. F. Kalscheur. 2007. Dried distillers grains plus solubles with corn silage or alfalfa hay as the primary forage source in dairy cow diets. J. Dairy Sci. 90:5587-5599.

Kononoff, P. J., A. J. Heinrichs, and D. R. Buckmaster. 2003. Modification of the Penn State forage and total mixed ration particle separator and the effects of moisture content on its measurements. J. Dairy Sci. 86:1858-1863.

Lammers, B. P., D. R. Buckmaster, and A. J. Heinrichs. 1996. A simple method for the analysis of particle sizes of forage and total mixed rations. J. Dairy Sci. 79:922-928.

Leonardi, C., and L. E. Armentano. 2003. Effect of quantity, quality, and length of alfalfa hay on selective consumption by dairy cows. J. Dairy Sci. 86:557-564.
Leonardi, C., F. Giannico, and L. E. Armentano. 2005. Effect of water addition on selective consumption (sorting) of dry diets by dairy cattle. J. Dairy Sci. 88:1043-1049.

Maesoomi, S. M., G. R. Ghorbani, M. Alikhani, and A. Nikkhah. 2006. Canola meal as a substitute for cottonseed meal in diet of midlactation Holsteins. J. Dairy Sci. 89:1673-1677.

Mertens, D. R. 1997. Creating a system for meeting the fiber requirements of dairy cows. J. Dairy Sci. 80:1463-1481.

National Research Council. 2001. Nutrient Requirements of Dairy Cattle. 7th rev. ed. National Academy Press, Washington, DC.

Nelson, W. F., and L. D. Satter. 1990. Effect of stage of maturity and method of preservation of alfalfa on production by lactating dairy cows. J. Dairy Sci. 73:1800-1811.

Nikkhah, A., M. Alikhani, and H. Amanlou. 2004. Effects of feeding ground or steam-flaked broom sorghum and ground barley on performance of dairy cows in midlactation. J. Dairy Sci. 87:122130.

Nordlund, K. V., and E. F. Garrett. 1994. Rumenocentesis: A technique for collecting rumen fluid for the diagnosis of subacute rumen acidosis in dairy herds. Bovine Pract. 28:109-112.

Onetti, S. G., S. M. Reynal, and R. R. Grummer. 2004. Effect of alfalfa forage preservation method and particle length on performance of dairy cows fed corn silage-based diets and tallow. J. Dairy Sci. $87: 652-664$.

Palmquist, D. L., and T. C. Jenkins. 1980. Fat in lactation rations: A review. J. Dairy Sci. 63:1-14.

Ruppert, L. D., J. K. Drackley, D. R. Bremmer, and J. H. Clark. 2003. Effects of tallow in diets based on corn silage or alfalfa silage on digestion and nutrient use by lactating dairy cows. J. Dairy Sci. 86:593-609.

Russell, J. B., and D. B. Wilson. 1996. Why are ruminal cellulolytic bacteria unable to digest cellulose at low $\mathrm{pH}$ ? J. Dairy Sci. 79:1503-1509.

SAS Institute. 2003. SAS Users' Guide. Version 9.1. Edition. SAS Institute Inc., Cary, NC.

Schwab, E. C.. R. D. Shaver, K. J. Shinners, J. G. Lauer, and J. G. Coors. 2002. Processing and chop length effects in brown-midrib corn silage on intake, digestion, and milk production by dairy cows. J. Dairy Sci. 85:613-623.

Smith, W. A., B. Harris Jr, H. H. Van Horn, and C. J. Wilcox. 1993 Effects of forage type on production of dairy cows supplemented with whole cottonseed, tallow, and yeast. J. Dairy Sci. 76:205215.

Staples, C. R., A. Amorocho, and F. Cullens. 2003. Fat-feeding practices for lactating dairy cows. Pages 52-64 in Proc.40th Annu. Florida Dairy Prod. Conf., University of Florida, Gainesville. Institute of Food and Agricultural Sciences and Florida Dairy Extension, Gainesville, FL.

Susenbeth, A., R. Mayer, B. Koehler, and O. Neumann. 1998. Energy requirement for eating in cattle. J. Anim. Sci. 76:2701-2705.

Van Keulen, V., and B. H. Young. 1977. Evaluation of acid-insoluble ash as natural marker in ruminant digestibility studies. J. Anim. Sci. 26:119-135.

Van Soest, P. J., J. B. Robertson, and B. A. Lewis. 1991. Methods for dietary fiber, neutral detergent fiber, and nonstarch polysaccharides in relation to animal nutrition. J. Dairy Sci. 74:3583-3597.

Welch, J. G. 1982. Rumination, particle size and passage from the. rumen. J. Anim. Sci. 54:885-894.

Yang, W. Z., K. A. Beauchemin, and L. M. Rode. 2000. Effects of barley grain processing on extent of digestion and milk production of lactating cows. J. Dairy Sci. 83:554-568. 